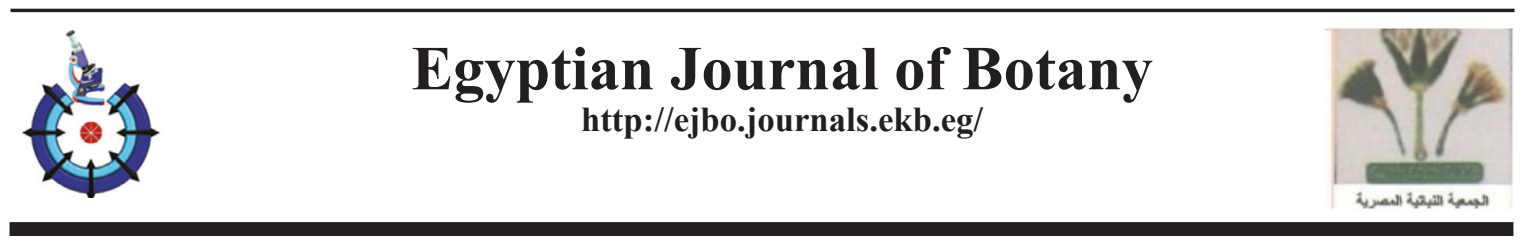

\title{
Isolation and Molecular Identification of Some Food Borne Pathogens from Raw and Processed Meats: In vitro Synergistic Probability of Lactobacillus CFS and Antibiotic
}

\author{
Mona M. Abou El Nour ${ }^{\#}$, Ebtehag A.E. Sakr \\ Botany Department, Faculty of Girls for Science, Education and Art, Ain Shams \\ University, Cairo, Egypt.
}

\begin{abstract}
$\mathbf{M}$ CROBIAL food safety is an important health concern; isolation of food-borne pathogens from available meat products is a bad indicator of poor hygienic practices. A Total of 200 samples of meats comprise beef burger, sausage, raw chicken and raw red meat ( 50 of each) were examined for hygienic quality by detecting the presence of potential bacterial food-borne pathogens. The highest frequency was recorded for E. coli $(48.25 \%)$ and Salmonella sp. (26.25\%) for the different meat samples, at the same time chicken meat was the most contaminated type. Isolates were identified by conventional bacteriological methods and confirmed by polymerase chain reaction using specific $16 \mathrm{~S}$ rRNA primer pairs. $B$. cereus was identified by targeting the presence of enterotoxin $n h e A$ and $B$ genes. Checking for the presence of shiga-toxin gene in E. coli $\mathrm{O} 517$ showed positive result. All confirmed isolates were tested for multidrug resistance characterization and found to be highly resistant to almost of the studied antibiotics. The most resistant strain was B. cereus $(75 \%)$ and the less efficient antibiotics were ampicillin and Sulfamethaxole/trimethoprim. Lactobacillus acidophilus cell free supernatant (CFS) showed efficient activity to inhibit the growth of all resistant isolates. Synergistic activity was detected when both agents (ampicillin \& CFR) were used in combination against $S$. aureus and $P$. aeruginosa.
\end{abstract}

Keywords: Food-borne pathogens, Lactobacillus, PCR, Synergism.

\section{Introduction}

Although nearly all foods contain adequate nutrients to support microbial growth but actually foods are complex medium that predicting how fast microorganisms will grow in any given food is difficult. In particular meat and meat products are good source of minerals, proteins and fatty acids, which offer a rich media for contamination (Komba et al., 2012). The presence of pathogenic strains in any food product give high indication for the non hygienic conditions in which these foods are prepared or stored (Cuny, 2010). Contamination can takes place at several stages along food chain production including processing, distribution, preparation, handling and marketing (Petersen \& James, 1998). Regarding safety concept, poultry meat considered first or second food associated with bacteria causing human diseases, Salmonella spp., Staphylococcus aureus, and rarely by Bacillus cereus are the most common diseases associated with consumption of contaminated poultry (Sams, 2001). Poultry slaughtering process in Egypt is commonly practiced in shops under poor hygienic and uncontrolled conditions in which possible contamination by pathogens may originate from the birds itself and from environmental factors as water, knives, tools, clothes, hands and air (Gill $\&$ Badoni, 2005). Meat, like any food, can cause certain diseases; meat is often contaminated from external sources during insanitary slaughtering places, bleeding, handling and transportation (Bhandare et al., 2007). Escherichia coli is commonly used as representative indicator, its presence in food generally indicated direct or

"Corresponding author email: monamn2003@yahoo.com

Received 19/11/2019; Accepted 19/12/2019

DOI: 10.21608/ejbo.2019.19837.1395

Edited by: Dr. Mahmoud S.M. Mohamed, Faculty of Science, Cairo University, Giza, Egypt.

C2020 National Information and Documentation Center (NIDOC) 
indirect fecal contamination (Abbassi-Ghozzi et al., 2011). Some strains are considered pathogenic or toxogenic as Shiga toxin-producing E. coli (STEC) which are genetically encoded by stx 1 and stx 2 genes. Escherichia coli $\mathrm{O} 157$ originating mainly from the intestinal tract during animal slaughter (Ikeme, 1990). Processed beef products such as minced meat, sausage, and burger are quick prepared meat meals that commonly contaminated with $B$. cereus which is one of the most dangerous food poisoning pathogen. Two types of food poisoning, emetic and diarrheal syndromes were induced by B. cereus group (Drobniewski, 1993). These syndromes are mainly the result of production of several enterotoxins: hemolytic enterotoxin (hblA, hblB, hblC, and hblD), Nonhemolytic (nheA, nheB, and nheC) and Cytotoxin $\mathrm{K}$ (ytK) (Pfrunder et al., 2016). Accordingly in the absence of sanitary conditions, raw meat products are responsible for a significant number of human food pathogens.

A new approach for identifying bacteria was developed in 1980; it was found that phylogenetic correlation of bacteria could be determined by matching a stable part of the genetic-code (Woese et al., 1985). The genes that code for the $5 \mathrm{~S}, 16 \mathrm{~S}$ and $23 \mathrm{~S}$ rRNA and the spaces between them were the applicants of this stable part. The most common part of DNA used now for taxonomic characters of bacteria is the $16 \mathrm{~S}$ rRNA gene (Harmsen \& Karch, 2004). Therefore Polymerase chain reaction (PCR) technique was considered as a simple and rapid method that has been successfully used for many food-borne pathogens identification (Ferretti et al., 2001)

Increased resistance among pathogens to commercial antibiotics due to the excessive and uncontrolled utilization of drugs led to many clinical problems throughout the world (Helmy et al., 2017) and the prevalence of pathogenic and nonpathogenic bacteria in different food animals, meat and meat products have an intensive role in the development and spread of new drug resistant strains (Farzana et al., 2009). The potential risk of antibiotic resistance in food-borne bacteria is of a great concern for public health. Reda et al. (2018) isolated $S$. aureus from 20 food samples (raw meat, raw poultry meat, raw milk, beef and cheese) and found that all are multi-drug resistant and 70\% of them are resistant to ampicillin, similar results were confirmed by Atef et al. (2017). In addition they identified the presence of enterotoxin genes using PCR assay. A good correlation between antibiotic resistance feature of pathogenic bacteria and the ability of biofilm formation was confirmed by Allam et al. (2019). Therefore, regarding the continuous emergence of multidrug resistant pathogens, a severe concern in looking for alternatives natural antibacterial agents with new modes of action has been increased.

Lactic acid bacteria are group of beneficial organisms that can potentially inhibit the growth of many food-borne pathogens by producing different potential metabolites (Verdenelli et al., 2009). The activity of lactic acid in combination with phenyllatic acids against three bread spoilage moulds was studied by Abouzeid (2011) and showed synergistic effect against the growth of two of them. Regarding the undesirable side effects of uncontrolled consumption of antibiotics, the LAB are natural organisms and their metabolites such as nisin, organic acids and bacteriocin are generally regarded as safe (Beristain-Bauza et al., 2016). Therefore one such solution to deal with drug resistance problem is the synergistic combination of antibiotic and effective probiotic which may offer higher antimicrobial activity with a reduced dose of the antibiotic and further prevent adverse side effects (Truusalu et al., 2008). Many authors (Brumfitt et al., 2002; Biswas et al., 2017) reported the synergetic combination of potential LAB strains or their supernatant with commercially available antibiotics. As the level of contamination of meat and its products with different food-borne pathogens represents serious problems for consumers, so the present study was done to examine the prevalence of food-borne pathogens definitely Salmonella sp., E. coli, S. aureus, B. cereus and P. aeruginosa in raw and processed meats. Resistance to antibiotics was evaluated in order to examine the inhibition effect of Lac. acidophillus cell free supernatant on these multidrug resistant strains. Synergistic probability of antibiotic and CFS combination was also investigated.

\section{Materials and Methods}

\section{Collection of samples}

Samples used in this study comprise two raw fresh meats (red and poultry meat) and two processed meat (beef burger and sausage) were collected from butchers, chicken slaughterhouses, and retail markets Giza province, Egypt. Fifty samples were aseptically taken from each type of 
meat; enclosed separately in sterile plastic bags and transported in ice-box to the laboratory and processed as soon as possible for detection and evaluation the presence of food born pathogenic bacteria.

Isolation and characterization of food borne pathogens

Samples preparation

For pre-enrichment, the meat samples were aseptically cut into smaller pieces with sterile knife and twenty five grams of each meat type was blended in $225 \mathrm{ml}$ of $1 \%$ sterile buffered peptone water (BPW) to obtain 1:10 $\left(10^{-1}\right)$ initial dilution. The homogenates were incubated aerobically at $37^{\circ} \mathrm{C}$ for $12-24 \mathrm{hrs}$ for primary enrichment.

\section{Bacteriological isolation}

Samples were cultured on selective agar medium for detection and isolation of the following pathogens. All obtained isolates were first identified by colony morphology and Gram staining then further identified biochemically by different bacteriological analysis and confirmed for $16 \mathrm{~S}$ rRNA by PCR assay.

\section{Media used for isolation of pathogenic bacteria Salmonella sp.}

One $\mathrm{ml}$ of each of the primary enriched BPW was added to $9 \mathrm{ml}$ of sterile tetrathionate broth for selective enrichment and incubated at $37^{\circ} \mathrm{C}$ for $24 \mathrm{hrs} .0 .1 \mathrm{ml}$ from each enriched sample was surface plated on Xylose Lysine Deoxycholate (XLD) agar (Oxoid, Basingstoke, UK (and incubated at $37^{\circ} \mathrm{C}$ for $18-24 \mathrm{hrs}$. Colonies that appeared pink to red with black centers on XLD agar were considered as Salmonella sp.

\section{Escherichia coli}

The primary enriched samples were further inoculated into sorbitol MacConkey broth for $24 \mathrm{hrs}$ at $37^{\circ} \mathrm{C}$ for secondary selective enrichment after which it was streaked onto Eosin Methylene Blue (EMB) agar (Oxoid, Basingstoke, UK), plates were incubated for $24 \mathrm{hrs}$ at $37^{\circ} \mathrm{C}$, typical colonies of $E$. coli appear to be green metallic shine on EMB media.

\section{Staphylococcus aureus}

One $\mathrm{ml}$ of each of the primary enriched BPW was added to $9 \mathrm{ml}$ nutrient broth for secondary enrichment and incubated at $37^{\circ} \mathrm{C}$ for $24 \mathrm{hrs}$ after that $0.1 \mathrm{ml}$ from each enriched sample was streaked on Mannitol Salt Agar (MSA) differential media for $S$. aureus. Plates were incubated at $37^{\circ} \mathrm{C}$ and examined after $24 \mathrm{hrs}$. Mannitol is fermented by S. aureus indicated by golden yellow colonies on MSA medium (Finegold \& Martin, 1982).

\section{Bacillus cereus}

Samples were enriched in the Tryptic Soy broth for $20 \mathrm{hrs}$ at $35^{\circ} \mathrm{C}, 0.1 \mathrm{ml}$ of the $20 \mathrm{hrs}$ enriched cultures were streaked on Bacillus cereus selective media Mannitol Egg Yolk Polymyxin (MYP) agar. Plates were incubated for $24 \mathrm{hrs}$ at $30^{\circ} \mathrm{C}$. Colonies will appear rough, dry and pink-orange in color surrounded by a zone of dense white precipitate indicating lecithinase production.

\section{Pseudomonas aeruginosa}

Cetrimide-nalidixic acid agar (CAN) was used for isolation of Pseudomonas aeruginosa, $0.1 \mathrm{ml}$ of each sample was spread on the media and incubated for $18 \mathrm{hrs}$ at $37^{\circ} \mathrm{C}$. Plates were examined by daylight for the detection of the yellow-green growth characteristic of $P$. aeruginosa (Goto \& Enomoto, 1970).

\section{Biochemical characterization}

All obtained isolates were subjected to biochemical characterization as described by Sneath et al. (2009) of determinative bacteriology for identification. Characterization of the isolates was done by performing specific tests including microscopic examination as Gram stain, cell shape, motility and sporulation also biochemical assays namely, $\mathrm{O}_{2}$ requirements, nitrate reduction coagulase, oxidase, catalase, urease, gelatin, starch and casein analysis, $\mathrm{H}_{2} \mathrm{~S}$ production, haemolytic activity on blood agar, indole production, methyl red, Voges-Proskauer, citrate utilization and sugar fermentation.

Molecular characterization of isolates using $16 \mathrm{~S}$ rRNA gene

All the isolated pathogens in this study were further confirmed by PCR using the species specific primer pairs of $16 \mathrm{~S}$ rRNA, the primer pairs were used for amplification of signature sequences in 16S rDNA variable regions 2 and 8 (V2 and V8) in each isolate (Table 1) and thus create a PCR amplicon with a certain molecular weight that can be recognized by gel electrophoresis. The biochemical approved strains were streaked on tryptic soy agar medium and incubated at $37^{\circ} \mathrm{C}$ for $24 \mathrm{hrs}$; a single colony of each strain was grown in Luria-Bertani (LB) broth medium and incubated at $37^{\circ} \mathrm{C}$ for $18-24 \mathrm{hrs}$. Bacterial genomic DNA 
was extracted according to Kit (Qiagen, German) manufacturer's instructions and used as DNA template. The DNA quantity and purity were measured spectrophotometrically at A260 and A280, as well as visualization on $1 \%$ agarose gel. The PCR amplification was done using reaction mixture $(25 \mu \mathrm{l})$ set as follows: $5 \mu \mathrm{l}$ of DNA template, $0.5 \mu 1$ of each primer, and $19 \mu 1$ of Taq PCR Master Mix polymerase (Qiagen, German), PCR amplification was carried out under the following conditions: initial denaturation $94^{\circ} \mathrm{C}$ for $5 \mathrm{~min}$ followed by 35 cycles of denaturation at $94^{\circ} \mathrm{C}$ for $1 \mathrm{~min}$, annealing $55^{\circ} \mathrm{C}$ for $1 \mathrm{~min}$ and elongation at $72^{\circ} \mathrm{C}$ for $1 \mathrm{~min}$ and final extension at $72^{\circ} \mathrm{C}$ for $7 \mathrm{~min}$. Molecular identification targeting gene producing enterotoxin A and B for Bacillus cereus and shiga toxin gene for $E$. coli were also performed using PCR technique previously described (Table 2).

\section{Antibiotic sensitivity test}

All the isolated pathogenic strains were evaluated for their sensitivity to antibiotics using 16 commercial antibiotic discs $(\mu \mathrm{g})$ from different groups. namely ampicillin (10), cefuroxime sodium (30), ceftriaxone (30), amikacin (30), chloramphenicol (30), Cefaclor (30), Aztroname (30), Vancomycin (10), Gentamycin (10), Erythromycin (15), Ciprofloxacin (5), Levofloxacin (5) Norfloxacin (30), Cefoxitin (30), Piperacillin (100) and Sulfamethaxole/ trimethoprim (25). The antibiotic susceptibility was carried out by disc diffusion assay on Mueller-
Hinton agar. Standard bacterial suspensions of the pathogens were prepared equivalent to 0.5O.D (McFarland standards) the suspension was spread on the surface of Mueller-Hinton agar media using a sterile cotton swab. The tested antibiotic discs were arranged on the surface of inoculated plates and incubated aerobically at $37^{\circ} \mathrm{C}$ for $18-24 \mathrm{hrs}$, after which the zone diameters were measured (mm) and compared with the standard measures given by Clinical and Laboratory Standards Institute (CLSI, 2017) as sensitive (S) or resistant (R). Resistance of Lactobacillus acidophilus La-5 to all tested antibiotics was also evaluated.

\section{Tested lactic acid bacteria.}

Lactic acid bacterial culture of Lactobacillus acidophilus La-5 (Chr. Hansen's Lab., Denmark) was assayed for its Cell Free Supernatant (CFS) ability to inhibit growth of the identified pathogens by agar well diffusion method (Devi Avaiyarasi et al., 2016). Lact. acidophilus La-5 was cultivated and maintained on deMan Rogosa Sharpe (MRS) media.

\section{Preparation of Lactobacillus acidophilus CFS}

Lact. acidophilus La-5 was inoculated in MRS broth medium and incubated at $37^{\circ} \mathrm{C}$ for $48 \mathrm{hrs}$. The bacterial suspension was centrifuged at $8000 \mathrm{rpm}$ for $20 \mathrm{~min}$. the pellet was throw away and the cellfree supernatant was obtained by filter-sterilized through a $0.2 \mu \mathrm{m}$-pore-size Whatman membrane filter (Sigma, USA) and used freshly (Marques et al., 2017).

TABLE 1. Primer sequences of $16 S$ rRNA genes for bacterial pathogens confirmation.

\begin{tabular}{|c|c|c|c|}
\hline Pathogenic strain & Primer sequence $\left(5^{\prime}-3^{\circ}\right)$ & $\begin{array}{l}\text { Amplicon } \\
\text { size (bp) }\end{array}$ & Reference \\
\hline Salmonella sp. & $\begin{array}{l}\text { 16S-Sal F.GTGTTGTGGTTAATAACCGCAGCA } \\
\text { 16S-CCR R.TGTTBGMTCCCCACGCTTTCG }\end{array}$ & 324 & Lin et al. (2004) \\
\hline P. aeruginosa & $\begin{array}{l}\text { PA-SS F.GGGGGATCTTCGGACCTCA } \\
\text { PA-SS R.TCCTTAGAGTGCCCACCCG }\end{array}$ & 956 & Altaai et al. (2014) \\
\hline S. aureus & $\begin{array}{l}\text { F.GTAGGTGGCAAGCGTTATCC } \\
\text { R.CGCACATCAGCGTCAG }\end{array}$ & 228 & Karmakar et al. (2016) \\
\hline E. coli $\mathrm{O} 157$ & $\begin{array}{l}\text { F. GTTTGATCCTGGCTCA } \\
\text { R.TACCAGGGTATCTAATCC }\end{array}$ & 300 & Magray et al. (2011) \\
\hline
\end{tabular}

TABLE 2. Primer sequences of enterotoxin primers of B. cereus and E. coli 0157 .

\begin{tabular}{|c|c|c|c|c|}
\hline Pathogenic strain & $\begin{array}{l}\text { Target } \\
\text { gene }\end{array}$ & Primer sequences $\left(5^{\prime}\right.$ and $\left.3^{6}\right)$ & $\begin{array}{c}\text { Amplified } \\
\text { segment (bp) }\end{array}$ & Reference \\
\hline $\begin{array}{l}\text { Bacillus cereus } \\
\text { (Enterotoxin gene) }\end{array}$ & $\begin{array}{c}\text { nhe } A \text { and } \\
\text { nhe } B\end{array}$ & $\begin{array}{l}\text { NA2 F AAG CIG CTC TTC GIA TTC } \\
\text { NB1 R ITI GTT GAA ATA AGC TGT GG }\end{array}$ & 766 & $\begin{array}{l}\text { Ehling-Schulz } \\
\text { et al. (2006) }\end{array}$ \\
\hline $\begin{array}{l}\text { E. coli } \mathrm{O} 157 \\
\text { (Shiga toxin gene) }\end{array}$ & $S T$ & $\begin{array}{l}\text { F. ATTTTTMTTTCTGTATTRTCTT } \\
\text { R. CACCCGGTACARGCAGGATT }\end{array}$ & 190 & $\begin{array}{l}\text { Aranda et al. } \\
\qquad(2004)\end{array}$ \\
\hline
\end{tabular}


Assessment the antibacterial activity of Lact. acidophilus against the pathogenic strains a-Qualitative method

Assessment of Lact. acidophilus activity was done using well diffusion assay, $30 \mu l$ of the aliquot CFS was placed in $7 \mathrm{~mm}$ diameter wells in Muller Hinton (MH) agar plates previously seeded with the pathogenic strains. Plates were left for solidification and then incubated at $37^{\circ} \mathrm{C}$ for $24 \mathrm{hrs}$. Lactobacillus-free broth was used as control, inhibition zones diameters were measured in mm (Sharma et al., 2017).

\section{b-Quantitative method (turbidity)}

Equal volumes of CFS of Lactobacillus and was mixed with bacterial suspensions of the pathogens equivalent to 0.5O.D (McFarland standards) in MH broth. The optical densities of culture media were measured at $0,2,4,6,12$, and $24 \mathrm{hrs}$ after incubation at $580 \mathrm{~nm}$ (Akujobi $\&$ Njoku, 2010). Percentage inhibition= $1-(\mathrm{OD}$ test/OD control) x 100

\section{Resistance of Lact. acidophilus to bile salt}

The ability of Lactobacillus to endure bile salt was examined by determine the optimal growth after incubating $\left(37^{\circ} \mathrm{C}\right)$ the Lactobacillus in MRS broth tubes containing different concentrations of bile salt $(0-3 \%)$. Bacterial growth was observed by measuring absorbance at $600 \mathrm{~nm}$ at different time intervals $(0-24 \mathrm{hrs})$. Bile salt-free MRS broth was used as control (François et al., 2012).

\section{Determination of minimum inhibitory concentrations}

The minimum inhibitory concentrations (MICs) of the less efficient antibiotic for all the identified strains were determined as well as the MIC of the cell free supernatant of the investigated Lact. acidophilus. Determination was done using broth micro-dilution assay in 96 wells polystyrene microtitre plate according to CLSI (2003) and CLSI, (2006). The antibiotic was dissolved for maximum concentration of $1 \mathrm{mg} / \mathrm{ml}$ in sterile distilled water; and $4 \mathrm{mg}$ of freeze-dried CFS in $1 \mathrm{ml}$ sterile distilled water as stock solutions. The antibiotic and the CFS were subjected to two-fold dilution series with MuellerHinton Broth and LB medium, respectively to obtain concentrations ranging from 2048 to $4 \mu \mathrm{g} / \mathrm{ml}$. Microtitre plate wells containing $90 \mu \mathrm{l}$ of bacterial suspensions $\left(10^{6} \mathrm{CFU} / \mathrm{ml}\right)$ and $10 \mu \mathrm{l}$ of each dilution of antibiotic and or CFS were incubated at $37^{\circ} \mathrm{C}$ for $24 \mathrm{hrs}$. CFS and antibiotic free broth wells were used as control. The lowest concentration (highest dilution) that completely inhibited microbial growth as determined by optical density measurements at $600 \mathrm{~nm}$ was considered the MIC value.

Synergistic evaluation of CFS and the tested antibiotic

Checkerboard assay was designed to evaluate the antimicrobial effect of combined antibiotic and CFS using 96-well micro-titre tray. Two- fold serial dilutions of the antibiotic and the CFS were prepared with concentrations ranging from 4 to $2^{\times} \mathrm{MIC}$ of each anti-agent. $25 \mu \mathrm{l}$ of each dilution of the antibiotic were added to the wells in vertical orientation and $25 \mu \mathrm{l}$ of each dilution of CFS were added to the wells in horizontal orientation so that the plate contained various concentrations of combinations of the two compounds. $50 \mu 1\left(10^{6}\right.$ $\mathrm{CFU} / \mathrm{ml}$ ) of bacterial suspension was added to each well, wells without antibacterial agents were used as positive control, and the plate was incubated at $37^{\circ} \mathrm{C}$ for $24 \mathrm{hrs}$. The Fractional Inhibitory Concentration (FIC) is the lowest concentration of anti-agents in combination permitting no visible growth of the test organism (Vidaillac et al., 2007). The FIC value for each agent was calculated using the formula:

$$
\begin{aligned}
& \text { FIC antibiotic }=\frac{\text { MIC of antibiotic in combination }}{\text { MIC of antibiotic alone }} \\
& \text { FIC supernatant }=\frac{\text { MIC supernatant in combination }}{\text { MIC supernatant alone }}
\end{aligned}
$$

The interaction between the antibiotic and the supernatant was assessed in terms of the FIC index calculated using the following formula:

\section{FIC index $=$ FIC antibiotic + FIC supernatant}

The interaction was defined as synergistic if the FIC index was $\leq 0.5$, partial synergy if the FIC index was $>0.5$ and less than or equal 1.0, and antagonistic if the FIC index was $>1.0$.

\section{Statistical analyses}

Means and standard deviation of the studied parameters were calculated. The data was statistically treated using two-way analysis of variance (univariate). The means were compared by least significant difference at $\mathrm{P}<0.05$. The statistical analysis was processed using SPSS version 16 (2006). 


\section{Results}

Prevalence of pathogens in studied meat samples

Raw and processed meats are a good medium with sufficient nutrients for microbial growth. Routine isolation and identification of the desired pathogens were done first based on cultural characteristics and biochemical characterization for each strain. The prevalence of isolated pathogens from the investigated food samples is summarized in Table 3. The results illustrated that all collected food meat samples were variably contaminated with bacterial pathogens, the higher level of contamination was found in chicken meat (32.8\%) and red meat (31\%) while obviously sausage is the least contaminated one. High prevalence percent of $E$. coli $(48.25 \%)$ was detected when compared to other investigated isolates with remarkable frequency in chicken meat $(80 \%)$, in addition the high frequency of Salmonella (41\%) was detected in chicken meat also.

\section{Biochemical characterization of the isolated pathogens}

The bacterial strains were identified first by isolation on selective media of each strain, colonies appeared red with black center, green metallic shine, golden yellow, pink-orange surrounded by a zone of dense white precipitate and yellowgreen were characterized for Salmonella sp., $E$. coli, $S$. aureus, B. cereus and $P$. aeruginosa in respective order on their specific media. Then after, the identified colonies were further subjected to recommended Bergey's manual bacteriological determination, results of all studied tests are recorded in Table 4.

\section{Molecular confirmation of biochemically tested isolates}

Biochemically confirmed isolates were further subjected to molecular characterization by PCR species specific primer pairs, the PCR amplicon with a certain molecular weight was identified by molecular weight comparison with the marker of a 100-bp DNA ladder and illustrated the existence of
16S rRNA at 956bp for $P$. aureginosa, at 324bp for Salmonella sp., (Fig. 1), at 228bp for $S$. aureus and at $300 \mathrm{bp}$ for E. coli O157 (Fig. 2). While B. cereus isolate was confirmed by the existence of desirable nhe $A$ and nhe $B$ enterotixin gene at 766bp specific band (Fig. 1). In addition, PCR amplicon detected the presence of shiga toxin gene in E. coli O517 isolate at specific band of 190bp size (Fig. 3).

\section{Antibiotic sensitivity determination}

All identified isolates examined for drug resistance pattern by disc diffusion technique showed high levels of resistance against almost all antibiotics used (Table 5). Moreover, all examined strains showed resistance (100\%) against Ampicillin ( $\beta$-lactam group) and Sulfamethaxole/ trimethoprim (sulfa drug group), while all are sensitive (100\%) against Vancomycin (Glycopeptides group), Amikacin, Gentamycin (Aminoglycosides group) and Norfloxacin (Quinolones \& fluoroquinolones group). $B$. cereus was tolerant to high number $(75 \%)$ of the antibiotics tested and $P$. aureginosa was tolerant to $19 \%$ only of the tested antibiotics. The Resistance pattern of the lactic acid bacterial strain used (Lac. acidophilus La5) was also investigated and clear resistance $(81 \%)$ to antibiotics tested was found.

Antimicrobial potency of Lac. acidophilus La5 cell free supernatant against all identified food borne strains was performed using agar well diffusion method which illustrated remarkable effect varied among strains with zone of inhibition in the range of 22 to $31 \mathrm{~mm}$ (Fig. 4). The CFS of Lac. acidophilus which containing different natural metabolites showed a potent inhibitory effect even against the highly drug resistant Bacillus cereus. Notably, both Gram-positive and Gram-negative bacteria were inhibited by the examined CFS. Furthermore, Percent inhibition of the CFS was also investigated along different time intervals (Fig. 5), results illustrated high percent inhibition and efficient activity starting from $12 \mathrm{hrs}$ incubation.

TABLE 3. Prevalence of pathogenic isolates in collected meat samples.

\begin{tabular}{lcccccc}
\hline \multirow{2}{*}{$\begin{array}{l}\text { Type of meat } \\
\text { (50 sample/each) }\end{array}$} & Salmonella sp. & E. coli & S. aureus & B. cereus & P. aerogenosa & \multirow{2}{*}{$\begin{array}{c}\text { Potal } \\
\text { \% }\end{array}$} \\
\cline { 2 - 6 } Red meat & 38 & 54 & 21 & 22 & 20 & 31 \\
chicken meat & 41 & 80 & 13 & 10 & 20 & 32.8 \\
Beef burger & 17 & 47 & 22 & 28 & 14 & 25.6 \\
sausage & 9 & 12 & 18 & 4 & 8 & 10.2 \\
Total \% & 26.25 & 48.25 & 18.5 & 16 & 15.5 & \\
\hline
\end{tabular}

Egypt. J. Bot. 60, No. 2 (2020) 
TABLE 4. Morphological and biochemical identification of pathogenic isolates.

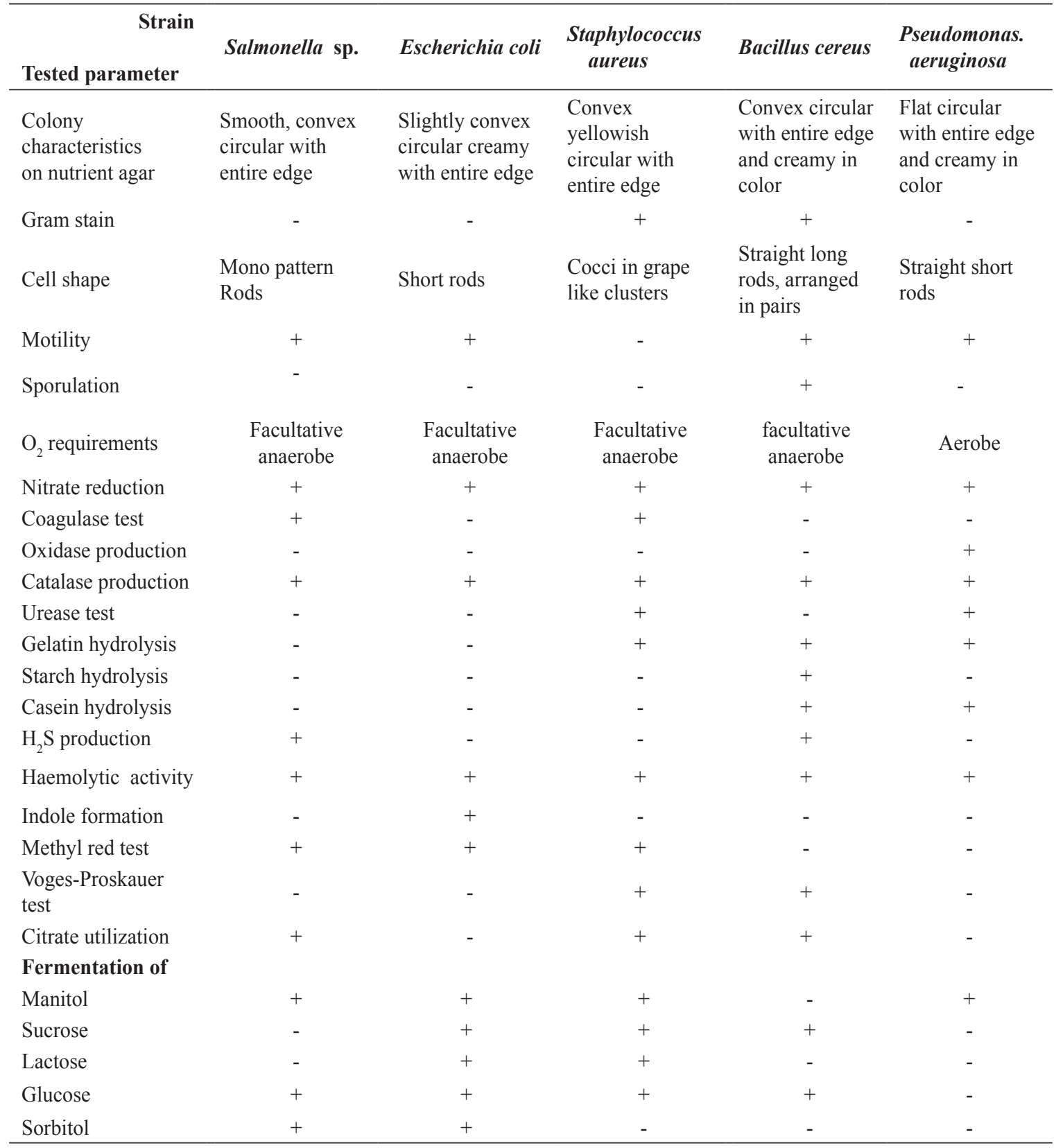

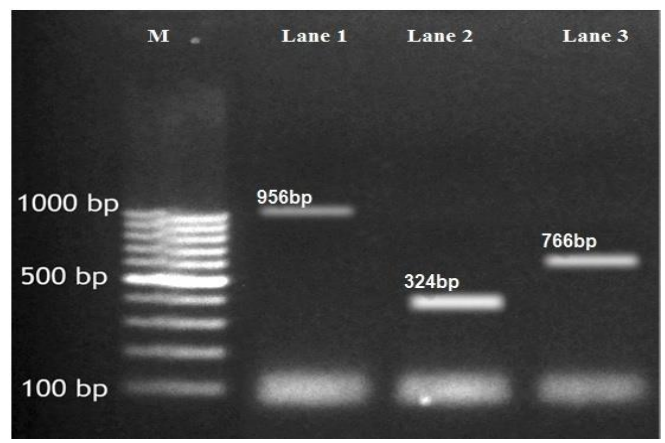

Fig. 1. Agarose gel electrophoresis showing amplified PCR products with 956bp segment 16S rRNA of $P$. aeruginosa (Lane 1) 324bp segment 16S rRNA of Salmonella sp. (Lane 2) and 766bp segment $n h e A$ and nhe $B$ enterotixin of $B$. cereus (Lane 3) [Lane M: 100bp DNA Ladder]. 


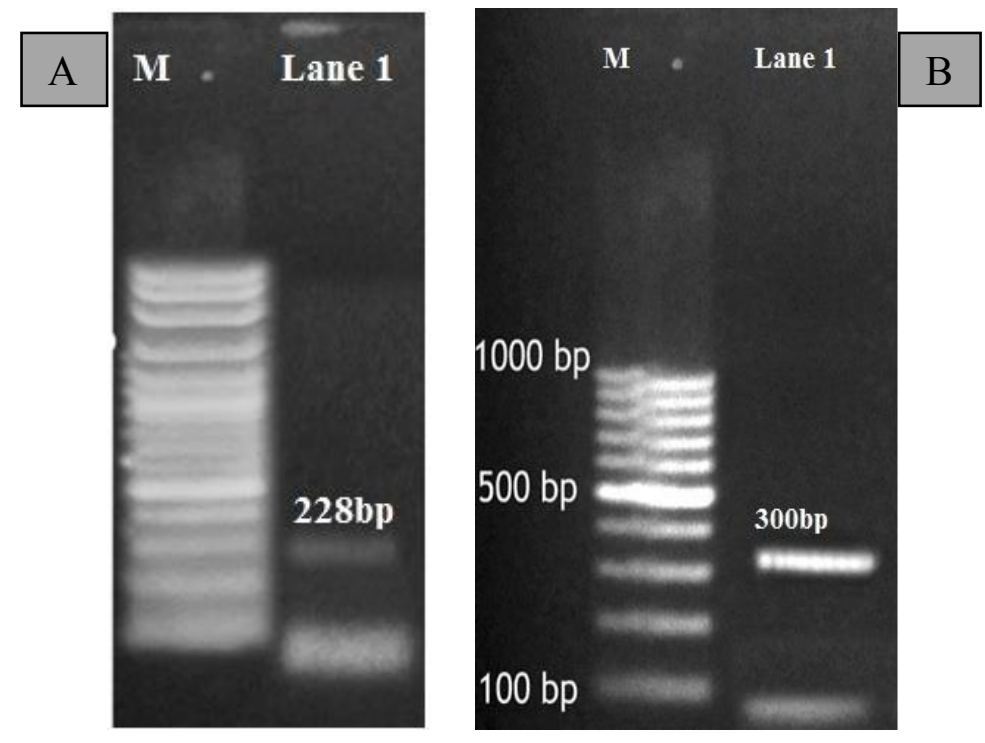

Fig. 2. Agarose gel electrophoresis showing amplified PCR products for $16 \mathrm{~S}$ rRNA (A) for $S$. aureus at 228bp, (B) for $E$. coli 0517 at 300bp. Lane M: 100 bp DNA Ladder.

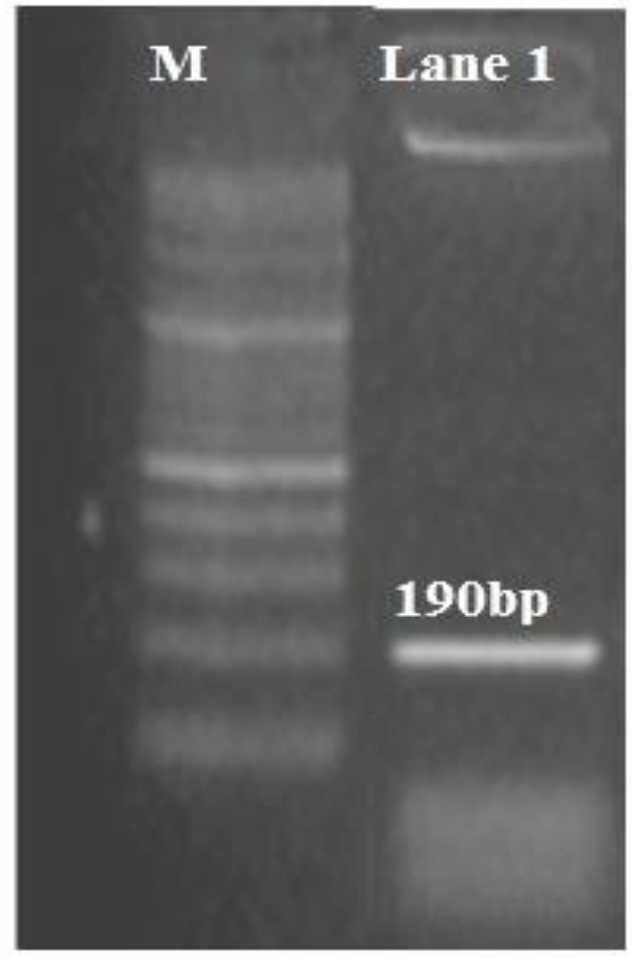

Fig. 3. Amplified PCR product of positive $S T$ gene of $E$. coli at 190bp (Lane 1) [Lane M, 100bp ladder].

Resistance of Lac. acidophilus to bile salt

The Lac. acidophilus strain used in this study was examined for its bile salt tolerance capability, bile salt concentrations ranging from 0.2 to $3 \%$ were examined, while $0 \%$ was considered as control. Results in Table 6 illustrate that bacterial growth did not inhibited completely even at high concentration of $2 \%$ and start to be reduced at 3\% bile salt but with no significant difference.

Determination of MICs for the most efficient antibiotic

All identified isolates were found to be resistant to the antibiotic ampicillin which belong to $\beta$-lactam group as shown from the previous sensitivity test, therefore it was chosen for MIC determination and further subjected to synergistic evaluation in combination with CFS of Lac. acidophilus. The MIC of the CFS was determined as well against all identified strains. The MICs values of ampicillin were found in the range of $1024-128 \mu \mathrm{g} / \mathrm{ml}$ (Table 7 ), while those of CFS were in the range of $512-64 \mu \mathrm{g} / \mathrm{ml}$ (Table 8). Staphyloccicus. aureus and Pseudomonas auregenosa were found to be the most resistant strains as indicated by the high MIC value recorded $(1024 \mu \mathrm{g} / \mathrm{ml})$. Furthermore, the result in the table illustrate that the highest antimicrobial activity of CFS was obtained against Bacillus cereus and Pseudomonas auregenosa as evident by the low MICs $(64 \mu \mathrm{g} / \mathrm{ml})$ obtained and proved by the wide inhibition zones $(29 \& 28 \mathrm{~mm})$ in agar plates. 
TABLE 5. Antibiotic sensitivity pattern of tested srains by disc-diffusion assay supernatant bioactivity antimicrobial .

\begin{tabular}{|c|c|c|c|c|c|c|c|c|c|}
\hline $\begin{array}{l}\text { Mode of } \\
\text { action }\end{array}$ & Antibio & ics groups & Antibiotics & $\begin{array}{c}\text { Salmonela } \\
\text { sp. }\end{array}$ & $\begin{array}{r}\text { E.coli } \\
\text { O157 } \\
\end{array}$ & $\begin{array}{c}S . \\
\text { aureus }\end{array}$ & $\begin{array}{c}\text { B. } \\
\text { cereus }\end{array}$ & $\begin{array}{c}P . \\
\text { aureg }\end{array}$ & $\begin{array}{c}\text { Lac. } \\
\text { acidophilus. }\end{array}$ \\
\hline \multirow{8}{*}{$\begin{array}{l}\text { Inhibitor of } \\
\text { cell wall }\end{array}$} & \multirow{7}{*}{$\beta$-lactam } & \multirow{2}{*}{ Penicillins } & Ampicillin (10) & $\mathrm{R}$ & $\mathrm{R}$ & $\mathrm{R}$ & $\mathrm{R}$ & $\mathrm{R}$ & $\mathrm{R}$ \\
\hline & & & Piperacillin(100) & $\mathrm{R}$ & $\mathrm{R}$ & $\mathrm{R}$ & $\mathrm{R}$ & $\mathrm{S}$ & S \\
\hline & & \multirow{4}{*}{$\begin{array}{l}\text { Cephalos- } \\
\text { porins }\end{array}$} & Ceftriaxone(30) & $\mathrm{R}$ & $\mathrm{R}$ & $\mathrm{R}$ & $\mathrm{R}$ & $\mathrm{S}$ & $\mathrm{R}$ \\
\hline & & & Cefoxitin(30) & $\mathrm{R}$ & $\mathrm{S}$ & $\mathrm{R}$ & $\mathrm{R}$ & $\mathrm{S}$ & $\mathrm{R}$ \\
\hline & & & $\begin{array}{l}\text { Cefuroxime } \\
\text { sodium }(30)\end{array}$ & $\mathrm{R}$ & $\mathrm{R}$ & $\mathrm{R}$ & $\mathrm{R}$ & $\mathrm{S}$ & $\mathrm{R}$ \\
\hline & & & Cefaclor(30) & $\mathrm{S}$ & $\mathrm{R}$ & $\mathrm{S}$ & $\mathrm{R}$ & $\mathrm{S}$ & $\mathrm{R}$ \\
\hline & & \multirow{2}{*}{$\begin{array}{l}\text { Monobactam } \\
\text { peptides }\end{array}$} & Aztroname (30) & $\mathrm{R}$ & $\mathrm{R}$ & $\mathrm{R}$ & $\mathrm{R}$ & $\mathrm{S}$ & $\mathrm{R}$ \\
\hline & Glyce & & Vancomycin(10) & $\mathrm{S}$ & S & $\mathrm{S}$ & $\mathrm{S}$ & $\mathrm{S}$ & $\mathrm{R}$ \\
\hline \multirow{4}{*}{$\begin{array}{l}\text { Inhibitor of } \\
\text { protein } \\
\text { synthesis }\end{array}$} & \multirow{2}{*}{\multicolumn{2}{|c|}{ Aminoglycosides }} & Gentamycin(10) & $\mathrm{S}$ & $\mathrm{S}$ & $\mathrm{S}$ & $\mathrm{S}$ & $\mathrm{S}$ & $\mathrm{R}$ \\
\hline & & & $\operatorname{Amikacin}(30)$ & S & S & $\mathrm{S}$ & S & S & S \\
\hline & \multicolumn{2}{|c|}{ Macrolids } & Erythromycin(15) & S & $\mathrm{R}$ & S & $\mathrm{R}$ & $\mathrm{R}$ & $\mathrm{R}$ \\
\hline & \multicolumn{2}{|c|}{ Phenicols } & $\begin{array}{l}\text { Chloramphenicol } \\
\text { (30) }\end{array}$ & $\mathrm{S}$ & $\mathrm{S}$ & $\mathrm{S}$ & $\mathrm{R}$ & $\mathrm{S}$ & $\mathrm{R}$ \\
\hline \multirow{3}{*}{$\begin{array}{l}\text { Inhibitors of } \\
\text { nucleic acid } \\
\text { synthesis }\end{array}$} & \multirow{3}{*}{\multicolumn{2}{|c|}{$\begin{array}{c}\text { Quinolones\& } \\
\text { fluoroquinolones }\end{array}$}} & Ciprofloxacin(5) & $\mathrm{R}$ & $\mathrm{S}$ & $\mathrm{R}$ & $\mathrm{R}$ & $\mathrm{S}$ & $\mathrm{S}$ \\
\hline & & & Levofloxacin(5) & $\mathrm{R}$ & $\mathrm{S}$ & S & $\mathrm{R}$ & S & $\mathrm{R}$ \\
\hline & & & Norfloxacin(30) & $\mathrm{S}$ & $\mathrm{S}$ & $\mathrm{S}$ & $\mathrm{S}$ & $\mathrm{S}$ & $\mathrm{R}$ \\
\hline $\begin{array}{l}\text { Anti- } \\
\text { metabolites }\end{array}$ & \multicolumn{2}{|c|}{ Sulfa drug } & $\begin{array}{l}\text { Sulfamethaxole/ } \\
\text { trimethoprim(25) }\end{array}$ & $\mathrm{R}$ & $\mathrm{R}$ & $\mathrm{R}$ & $\mathrm{R}$ & $\mathrm{R}$ & $\mathrm{R}$ \\
\hline Resistance \% & & & & 56 & 50 & 50 & 75 & 19 & 81 \\
\hline
\end{tabular}

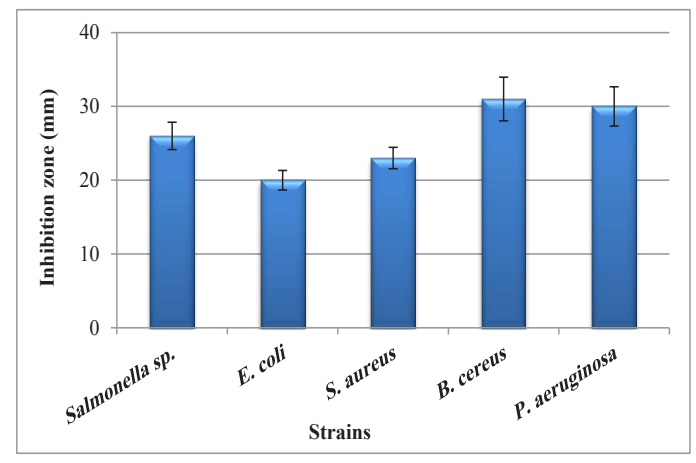

Fig. 4. Antimicrobial activity of Lac. acidophilus CFS against bacterial strains.

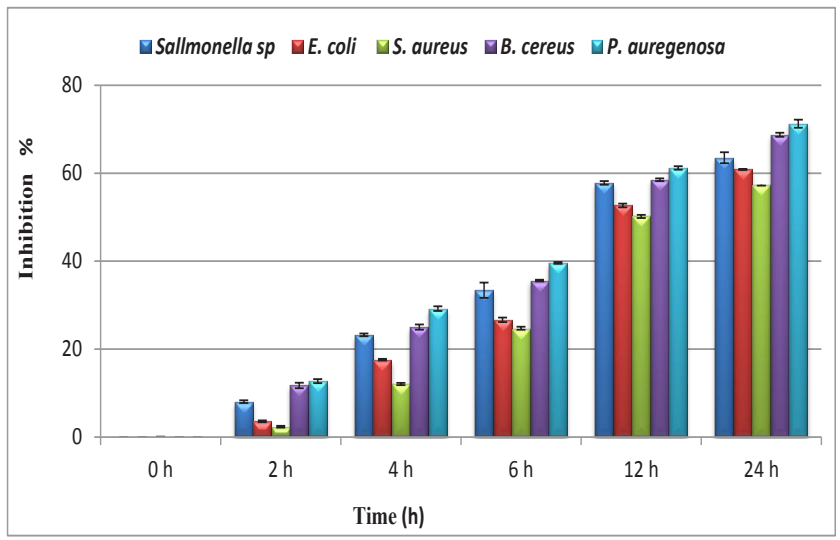

Fig. 5. Percent inhibition of Lac. acidophilus CFS against bacterial strains at different time interval. 
TABLE 6 . Effect of bile salt concentration on percent survival of Lac. acidophilus at different incubation time.

\begin{tabular}{lcccccc}
\hline $\begin{array}{l}\text { Bile salt conc. } \\
\text { (\%) }\end{array}$ & $\mathbf{0}$ & $\mathbf{2}$ & $\mathbf{4}$ & $\mathbf{6}$ & $\mathbf{2 4}$ & $\begin{array}{c}\text { Overall } \\
\text { mean }\end{array}$ \\
\cline { 2 - 6 } Zero (control) & $100 \pm 0.00$ & $100 \pm 0.00$ & $100 \pm 0.00$ & $100 \pm 0.00$ & $100 \pm 0.00$ & $100 \pm 0.00$ \\
0.2 & $100 \pm 0.00$ & $100.21 \pm 1.82$ & $94.67 \pm 0.58$ & $90.50 \pm 2.44$ & $89.22 \pm 0.29$ & $94.92 \pm 4.90$ \\
0.3 & $100.00 \pm 0.00$ & $97.38 \pm 2.60$ & $89.16 \pm 1.88$ & $79.98 \pm 2.11$ & $80.78 \pm 0.08$ & $89.46 \pm 8.65$ \\
0.4 & $100.00 \pm 0.00$ & $64.58 \pm 1.45$ & $55.39 \pm 0.36$ & $46.37 \pm 1.25$ & $61.73 \pm 0.17$ & $65.61 \pm 18.95$ \\
0.6 & $100.00 \pm 0.00$ & $56.83 \pm 0.81$ & $49.80 \pm 0.46$ & $43.69 \pm 1.18$ & $47.49 \pm 0.11$ & $59.56 \pm 21.40$ \\
0.8 & $100.00 \pm 0.00$ & $51.80 \pm 1.35$ & $44.54 \pm 0.95$ & $43.28 \pm 1.32$ & $44.10 \pm 0.17$ & $56.74 \pm 22.62$ \\
1 & $100.00 \pm 0.00$ & $37.38 \pm 0.70$ & $33.26 \pm 0.08$ & $27.07 \pm 0.77$ & $32.33 \pm 0.18$ & $46.01 \pm 28.15$ \\
2 & $100.00 \pm 0.00$ & $29.45 \pm 0.27$ & $23.72 \pm 0.19$ & $25.66 \pm 0.44$ & $12.61 \pm 0.17$ & $38.29 \pm 32.46$ \\
3 & $100.00 \pm 0.00$ & $21.08 \pm 0.19$ & $17.70 \pm 0.72$ & $8.81 \pm 0.15$ & $6.60 \pm 0.23$ & $30.84 \pm 36.23$ \\
Overall mean & $100.00 \pm 0.00$ & $62.08 \pm 29.70$ & $56.47 \pm 29.86$ & $51.71 \pm 30.26$ & $52.76 \pm 31.67$ & \\
\hline \multicolumn{7}{c}{ For Bile salt $\rightarrow 1.45$} \\
LSD at 0.05 & \multicolumn{7}{c}{ For time $\rightarrow 0.55$} & & & \\
\end{tabular}

TABLE 7. Identified MICs of ampicillin for the investigated pathogenic meat products.

\begin{tabular}{lc}
\hline Bacterial strains & MIC $(\boldsymbol{\mu g} / \mathbf{m l})$ \\
\hline Salmonella sp. & 128 \\
E. coli $\mathrm{O} 157$ & 512 \\
S. aureus & 1024 \\
B. cereus & 256 \\
P. auregenosa & 1024 \\
\hline
\end{tabular}

TABLE 8. Identified MICs of CFS for the investigated pathogenic meat products.

\begin{tabular}{lc}
\hline Bacterial strains & MIC $(\boldsymbol{\mu g} / \mathbf{m l})$ \\
\hline Salmonella $\mathrm{sp}$. & 128 \\
E. coli O517 & 512 \\
S. aureus & 512 \\
B. cereus & 64 \\
P. auregenosa & 64 \\
\hline
\end{tabular}

Evaluation of synergistic effect of antibiotic and CFS

The use of double combinations of antibiotic drugs with positive in vivo natural antimicrobial agents is usually of an interesting importance. Results in Tables 9 and 10 demonstrate that the MICs of the individual antiagents were comparatively high. The checkerboard broth microdilution method used for the combined evaluation of the antibiotic ampicillin and the CFS showed a marked reduction in the MIC against $S$. aureus from 1024 to $256 \mu \mathrm{g} / \mathrm{ml}$ for ampicillin and from 512 to $128 \mu \mathrm{g} / \mathrm{ml}$ for the CFS. While it was reduced for $P$. auregenosa from 1024 to $128 \mu \mathrm{g} / \mathrm{ml}$ for ampicillin and from 64 to $16 \mu \mathrm{g} / \mathrm{ml}$ for the CFS.

Fractional inhibitory concentration for S. aureus were:

FIC antibiotic $=\frac{256}{1024}=0.25$

FIC supernatant $=\frac{128}{512}=0.25$

FIC index $=0.25+0.25=0.5$

Fractional inhibitory concentration for $P$. auregenosa were:

FIC antibiotic $=\frac{128}{1024}=0.125$

FIC supernatant $=\frac{16}{64}=0.25$

FIC index $=0.125+0.25=0.375$

Since the interaction was considered as synergistic if the FIC index is $\leq 0.5$ therefore synergistic effect was verified by this combinations in which synergism is more efficient against $P$. auregenosa. 
TABLE 9 . Combined effect of ampicillin antibiotic and cell free supernatant against S. aureus.

\begin{tabular}{|c|c|c|c|c|c|c|c|c|c|c|c|}
\hline \multirow{11}{*}{ 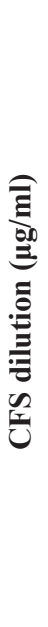 } & & \multicolumn{10}{|c|}{ Ampicillin dilution $(\mu \mathrm{g} / \mathrm{ml})$} \\
\hline & & 4 & 8 & 16 & 32 & 64 & 128 & 256 & 512 & 1024 & 2048 \\
\hline & 4 & + ve & $+\mathrm{ve}$ & $+\mathrm{ve}$ & $+\mathrm{ve}$ & $+\mathrm{ve}$ & $+\mathrm{ve}$ & $+\mathrm{ve}$ & $+\mathrm{ve}$ & -ve & - ve \\
\hline & 8 & $+\mathrm{ve}$ & $+\mathrm{ve}$ & $+\mathrm{ve}$ & $+\mathrm{ve}$ & $+\mathrm{ve}$ & $+\mathrm{ve}$ & $+\mathrm{ve}$ & $+\mathrm{ve}$ & -ve & -ve \\
\hline & 16 & $+\mathrm{ve}$ & $+\mathrm{ve}$ & $+\mathrm{ve}$ & $+\mathrm{ve}$ & $+\mathrm{ve}$ & $+\mathrm{ve}$ & $+\mathrm{ve}$ & $+\mathrm{ve}$ & -ve & -ve \\
\hline & 32 & $+\mathrm{ve}$ & $+\mathrm{ve}$ & $+\mathrm{ve}$ & $+\mathrm{ve}$ & $+\mathrm{ve}$ & $+\mathrm{ve}$ & $+\mathrm{ve}$ & $+\mathrm{ve}$ & -ve & -ve \\
\hline & 64 & + ve & $+\mathrm{ve}$ & $+\mathrm{ve}$ & $+\mathrm{ve}$ & $+\mathrm{ve}$ & + ve & $+\mathrm{ve}$ & + ve & -ve & -ve \\
\hline & 128 & $+\mathrm{ve}$ & $+\mathrm{ve}$ & $+\mathrm{ve}$ & $+\mathrm{ve}$ & $+\mathrm{ve}$ & $+\mathrm{ve}$ & -ve & -ve & -ve & -ve \\
\hline & 256 & $+\mathrm{ve}$ & $+\mathrm{ve}$ & $+\mathrm{ve}$ & $+\mathrm{ve}$ & $+\mathrm{ve}$ & $+\mathrm{ve}$ & -ve & -ve & -ve & -ve \\
\hline & 512 & $+\mathrm{ve}$ & $+\mathrm{ve}$ & $+\mathrm{ve}$ & $+\mathrm{ve}$ & + ve & $+\mathrm{ve}$ & -ve & -ve & -ve & -ve \\
\hline & 1024 & + ve & $+\mathrm{ve}$ & $+\mathrm{ve}$ & $+\mathrm{ve}$ & $+\mathrm{ve}$ & + ve & -ve & -ve & -ve & $-\mathrm{ve}$ \\
\hline
\end{tabular}

TABLE 10 . Combined effect of ampicillin antibiotic and cell free supernatantagainst $P$. auregenosa.

\begin{tabular}{|c|c|c|c|c|c|c|c|c|c|c|c|}
\hline \multirow{6}{*}{ 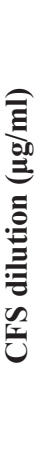 } & & \multicolumn{10}{|c|}{ Ampicillin dilution $(\mu \mathrm{g} / \mathrm{ml})$} \\
\hline & & 4 & 8 & 16 & 32 & 64 & 128 & 256 & 512 & 1024 & 2048 \\
\hline & 8 & $+\mathrm{ve}$ & $+\mathrm{ve}$ & + ve & $+\mathrm{ve}$ & + ve & $+\mathrm{ve}$ & $+\mathrm{ve}$ & $+\mathrm{ve}$ & -ve & -ve \\
\hline & 32 & $+\mathrm{ve}$ & $+\mathrm{ve}$ & + ve & $+\mathrm{ve}$ & $+\mathrm{ve}$ & -ve & -ve & -ve & -ve & -ve \\
\hline & 64 & $+\mathrm{ve}$ & $+\mathrm{ve}$ & + ve & $+\mathrm{ve}$ & $+\mathrm{ve}$ & -ve & -ve & -ve & -ve & -ve \\
\hline & 128 & $+\mathrm{ve}$ & + ve & + ve & $+\mathrm{ve}$ & $+\mathrm{ve}$ & -ve & -ve & -ve & -ve & -ve \\
\hline
\end{tabular}

\section{Discussion}

Foods, by their nature considered suitable substrates for the growth and metabolism of all microorganisms, especially meats are ideal media for growth of different organisms including those food-borne pathogens. Results of this study proved that all collected retailed meat samples were highly contaminated with different types of pathogens with high frequency for E. coli and Salmonella sp.; they were all found to be multi drug resistant. These results are in good accordance with results obtained by Saud et al. (2019). Our results are also in agreement with Moawad et al. (2017) who reported high incidence of $S$. enterica and E. coli as food borne pathogens found in poultry and beef meat in Egypt. In addition they recorded variable resistance of pathogens to antimicrobial agents with complete resistance to ampicillin and trimethoprim/ sulphamethoxazole in accordance with many other studies (Ahmed \& Shimamoto, 2014; Bantawa et al., 2018), while most isolates are sensitive to chloramphenicol and enrofloxacin.
Further reported results by Shahat et al. (2019) demonstrated one hundred percent resistance of $P$. aeruginosa to ampicillin and sulphamethazone while higher sensitivity was detected against ciprofloxacin and norfloxacin which is in line with present results. Gill \& McGinnis (2000) suggested that each step in the long chain of slaughtering and transportation of raw meat causes a potential risk of microbial contamination to the raw meat sold at retail outlets. It has been suggested that more than one factor may contributes to the existence of food borne pathogen contamination, contamination may be bring into food by workers indirectly by sneezing coughing or somewhat skin injury or indirectly through cloths, working surfaces, boxes, knives and equipment in general (Bhandare et al., 2007). The highest contamination rates may be related to the raw nature chicken and red meat, while the lowest contamination rate of sausage and beef burger can be explained that these two products considered half-processed meat and were subjected to heat treatment during manufacture, besides the addition of chemical preservatives, 
additives and spices during processing (Waters et al., 2011).

Polymerase chain reaction (PCR) is a very efficiently used in rapid detection of foodborne pathogens and has become a vital tool in molecular problems-solving (Pinto et al., 2005). Biochemically identified isolates of the current work were successfully confirmed by PCR technique using species specific primers $16 \mathrm{~S}$ rRNA, these results were supported by Lin et al. (2004) for Salmonella sp., Altaai et al. (2014) for P. aerogenosa, Shahat et al. (2019) for $S$. aureus and Magray et al. (2011) for E. coli. PCR is also a rapid technique for the verification of toxigenic $B$. cereus in food; in the current study the enterotoxin encoding genes nhe $A$ and nhe $B$ was assessed using specific primer set that previously agreed by Ehling-Schulz et al. (2006). PCR assay also detected the presence of Shiga toxin-producing gene in accordance with Aranda et al. (2004).

The antibiotic resistance of pathogens is one of the main problems resulting mainly from the inappropriate prescription and utilization of antibiotic drugs (Oli et al., 2017). Since all isolated pathogens of the present study showed high resistance to different classes of antibiotics therefore ampicillin was chosen for MIC determination against all investigated isolates. According to Reddy et al. (2017) isolates can be considered as MDR they are resistant to antibiotics belonging to the three different classe (aminoglycosides, quinolone and, cephalosporins). Staphyloccicus aureus and Pseudomonas auregenosa were the most resistance with high MIC values; accordingly ampicillin was examined for synergism possibility with cell free supernatant of tested Lactobacillus. Resistance towards different antibiotic drugs amongst pathogens including food-borne pathogens is a global problem. Lactic acid bacteria are widely used as probiotics and their metabolites such as acid, hydrogen peroxide, and bacteriocin are generally considered as safe and can inhibit many patho genic bacteria and fungi (Beristain-Bauza, 2016). Potential inhibitory effect was performed by the studied Lac. acidophilus against all pathogenic isolates, the present results were in good accordance with those obtained by Al-Madboly \& Abdullah (2015) who recorded high inhibition zone diameters (36 to $44 \mathrm{~mm}$ ) by different LAB strains against resistant S.aureus, 35 to $37 \mathrm{~mm}$ against E.coli and $28 \mathrm{~mm}$ against $S$. typhi. Results were also correspond to the findings of Bajpai et al. (2016a) who observed inhibition zone diameters ranging from16.5$20.4 \mathrm{~mm}$ and MIC values from 250-500 $\mu \mathrm{g} /$ ml. Cox et al. (2001) explained that leakage of different important electrolytes such as potassium ions, which contribute in different cell membrane functions can cause bacterial cell membrane disruption, thus induce cell death. In this respect Bajpai et al. (2016b) observed that inhibitory effects of CFS of LAB were confirmed to cause potassium ion efflux. The same authors have been reported inhibitory effect of CFS or LAB on nucleic acid liberation from bacterial pathogens which might give good indicator of membrane damage. Since effective probiotics should introduce their antimicrobial actions mainly to the pathogens in the gastrointestinal (GI) system (Samot \& Badet, 2013) therefore the degree of bile salt tolerance which is the most important stress factor in the GI tract was examined for the test Lac. acidophillus and illustrated visible growth at bile salt concentrations of 0.2 to $3 \%$. In consistent, Al-Madboly \& Abdullah (2015) reported that different bile concentration did not inhibit the bacterial growth completely and that high counts of bacteria were obtained even at a concentration of $2 \%$. They suggested a stress adaptation mechanism which could explain the increased growth. Another cause that may explain the bile resistance is the bile salt hydrolase (BSH) activity which is observed in some strains, thereby decreasing its bactericidal effect, and this may explain the sensitivity of some strains that do not have BSH activity (Suskovic et al., 2001).

The LAB can produce a wide range of inhibitory compounds including bacteriocins, organic acids, ethanol, diacetyl, carbon dioxide, and hydrogen peroxide (Liao \& Nyachoti, 2017). Ricke (2003) clarified that organic acids can reduce the intracellular $\mathrm{pH}$ which slows down the active transport of internal protons leading to excess ATP consumption resulting to cellular energy depletion. Surendran Nair et al. (2017) and Zhitnitsky et al. (2017) explained that the main targets of organic acids are the bacterial cell wall and cytoplasmic membrane of pathogens ending with their disturbance and death. Mitchell et al. (2015) deduced that hydrogen peroxide can act against non catalase producers pathogenic bacteria by enhancing toxic oxidation through superoxide anion chain reaction. LAB-bacteriocins are considered now as new field of antibiotics with 
potent in vitro and in vivo activities (Seddik et al., 2017). Moreover, Combinations of LABbacteriocins and antibiotics are arrising as new therapeutic alternatives for food-producing animals (Naghmouchi et al., 2013; Al Atya et al., 2016). The use of dual combinations of antimicrobial agents with positive in vitro interactions has become an important concern to potentiate the therapeutic action of antibiotics. In the present study the combination of ampicillin with CFS showed synergistic activity when tested against Staphyloccicus aureus and Pseudomonas auregenosa. Adwan \& Mhanna (2008) suggested that the additive effect of antimicrobial agent in combination with antibiotics may takes place as a result of double attack of both agents to different target sites of the cell. Nowadays, many natural antimicrobial agents were analyzed for their action as resistance-modifying agents and are expected to adjust or inhibit bacterial resistance or increasing the efficiency of antibiotics to destroy resistant bacteria (Abreu et al., 2013).

\section{Conclusion}

It is worth mentioning that all collected meat samples were contaminated with MDR isolates which confirm that slaughtering places show bad hygienic conditions, furthermore meats were purchased in open-air area without adequate control which contributes greatly to the development of resistance in the bacterial flora. These may highlight the need of strict control by the Ministry of Health. In addition it is expected that the use of effective combinations (synergistic) may avoid the increasing resistant development of pathogens that occur during antibiotic treatments and or reduce the antibiotic doses and side effects.

Competing Interest: The authors confirm that there are no known conflicts of interest associated with this manuscript.

Aknowledgment: Authors would like to thank Pr. Dr. Mona Mabrouk at National Organization of Drug Control and Research (NODCAR), Cairo, Egypt, for the help during carrying out the mole cular identification (PCR) experiment.

\section{References}

Abbassi-Ghozzi, I., Jaouani, A., Hammami, S., Martinez-Urtaza, J., Boudabous, A., Gtari, M. (2011) Molecular analysis and antimicrobial resistance of salmonella isolates recovered from raw meat marketed in the area of "Grand Tunis", Tunisia. Pathologie Biologie, 60(5), 49-54.

Abouzeid (2011) Antifungal activity of lactic and phenyllatic acids against bread spoilage moulds. Egyptian Journal of Botany, 51(1), 37-48.

Abreu, A.C., Tavares, R.R., Borges, A., Mergulhão, F., Simões, M. (2013) Current and emergent strategies for disinfection of hospital environments. Journal of Antimicrobial Chemotherapy, 68, 2718-2732.

Adwan, G., Mhanna, M. (2008) Synergistic effects of plant extracts and antibiotics on Staphylococcus aureus strains isolated from clinical specimens. Middle-East Journal of Scientific Research, 3, 134139.

Ahmed, A.M., Shimamoto, T. (2014) Isolation and molecular characterization of Salmonella enterica, Escherichia coli $\mathrm{O} 157: \mathrm{H} 7$ and Shigella spp. from meat and dairy products in Egypt. International Journal of Food Microbiology. 168-169, 57-62.

Akujobi, C.O., Njoku, H.O. (2010) Bioassay for the Determination of Microbial Sensitivity to Nigerian Honey. Global Journal of Pharmacology, 4(1), 36-40.

Al Atya, A.K., Belguesmia, Y., Chataigne, G., Ravallec, R., Vachée, A., Szunerits, S., Boukherroub, R., Drider, D. (2016) Anti-MRSA activities of enterocins DD28 and DD93 and evidences on their role in the inhibition of biofilm formation. Frontiers in Microbiology, 7, 817.

Allam, Nanis G., Shabana, Samia A., Osman, Y.A., Nouh, Hoda S. (2019) Prevalence of some virulence factors among Gram-negative bacteria isolated from patients with lung infection and their antimicrobial susceptibility patterns. Egyptian Journal of Botany, 59(3), 633-643.

Al-Madboly, L.A., Abdullah, A.K. (2015) Potent antagonistic activity of Egyptian Lactobacillus plantarum against multi resistant and virulent food-associated pathogens. Frontiers in Microbiology, 6, 347.

Altaai, M.E., Aziz, I.H., Marhoon, A.A. (2014) Identification Pseudomonas aeruginosa by 16s rRNA gene for differentiation from other Pseudomonas species that isolated from patients 
and environment. Baghdad Science Journal, 11(2), 1028-1034.

Aranda, K.R.S., Fagundes-Neto, U., Scaletsky, I.C.A. (2004) Evaluation of multiplex PCRs for diagnosis of infection with diarrheagenic Escherichia coli and Shigella spp. Journal of Clinical Microbiology, 42(12), 5849-5853.

Atef, H., Badr, N.H., Amer, W.M., Abd EL-Raheem, L.F. (2017) Efficiency of Egyptian plant extracts on the antibiotic susceptible and resistant pathogenic bacterial isolates. Egyptian Journal of Botamy, 57(3) $457-467$.

Bajpai, V.K., Han, J.H., Nam, G.J., Majumder, R., Park, C., Lim, J., Paek, W.K., Rather, I.A., Park, Y.H. (2016a) Characterization and pharmacological potential of Lactobacillus sakei 1I1 isolated from fresh water fish Zacco koreanus. DARU-Journal of Faculty of Pharmacy, 24(1), 8. doi: 10.1186/ s40199-016-0147-8.

Bajpai, V.K., Rather, I.A., Majumder, R., Alshammari, F.H., Nam, G.J., Park, Y.H. (2016b) Characterization and antibacterial mode of action of lactic acid bacterium Leuconostoc mesenteroides HJ69 from Kimchi. Journal of Food Biochemistry, 41(1). doi: 10. 1007/s00284-010-9855-3

Bantawa, K., Rai, K., Subba Limbu, D., Khanal, H. (2018) Foodborne bacterial pathogens in marketed raw meat of Dharan, eastern Nepal. BMC Research Notes, 11(1), 618 .

Beristain-Bauza, S.C., Opez, E.M.L., Palou, E., Malo, A.L.O. (2016) Antimicrobial activity and physical properties of protein films added with cell-free supernatant of Lactobacillus rhamnosus. Food Control, 62, 44-51.

Bhandare, S.G., Sherikarv, A.T., Paturkar, A.M., Waskar, OV.S., Zende, R.J. (2007) A comparison of microbial contamination on sheep/goat carcasses in a modern Indian abattoir and traditional meat shops. Food Control, 18, 854-868.

Biswas, K., Upadhayay, S., Rapsang, G.F., Joshi, S.R. (2017) Antibacterial and synergistic activity against b-Lactamase-producing nosocomial bacteria by bacteriocin of LAB isolated from lesser known traditionally fermented products of India. HAYATI Journal of Biosciences, 24, 87-95.
Brumfitt, W., Salton, M.R., Hamilton-Miller, J.M. (2002) Nisin, alone and combined with peptidoglycan-modulating antibiotics: activity against methicillin-resistant Staphylococcus aureus and vancomycin-resistant enterococci. Journal of Antimicrobial Chemotherapy, 50, 731-4.

Clinical and Laboratory Standards Institute (CLSI) (2003) Methods for dilution antimicrobial susceptibility test for bacteria that grow aerobically; Approved Standard M7-A6, $6^{\text {th }}$ ed., 2003. National Committee for Clinical Laboratory Standards, Wayne, Philadelphia.

Clinical and Laboratory Standards Institute (CLSI) (2006) Performance standards for antimicrobial susceptibility testing, $16^{\text {th }}$ Informational Supplement M100-S16, 2006. National Committee for Clinical Laboratory Standards, Wayne, Philadelphia.

Clinical Laboratory standard institute (CLSI) (2017) M26-TNCCLS. Methods for determining bactericidal activity of antimicrobial agents. Villanova.

Cox, S.D., Mann, C.M., Markhan, J.L., Gustafson, J.E., Warmington, J.R., Wyllie, S.G. (2001) Determining the antimicrobial action of tea tree oil. Molecules, 6, 87-91.

Cuny, C., Friedrich, A., Kozytska, S., Layer, F., Nübel, U., Ohlsen, K., Strommenger, B., Walther, B., Wieler, L., Witte, W. (2010) Emergence of methicillin-resistant Staphylococcus aureus (MRSA) in different animal species. International Journal of Medical Microbiology, 300, 109-117.

Devi Avaiyarasi, N., David Ravindran, A., Venkatesh, P., Arul, V. (2016) In vitro selection, characterization and cytotoxic effect of bacteriocin of Lactobacillus sakei GM3 isolated from goat milk. Food Control, 69, 124-133.

Drobniewski, F.A. (1993) Bacillus cereus and related species. Clinical Microbiology Reviews, 6(4), 324338.

Ehling-Schulz, M., Guinebretiere, M.H., Monthan, A., Berge, O., Fricker, M., Svensson, B. (2006) Toxin gene profiling of enterotoxic and emetic Bacillus cereus. FEMS Microbiology Letters, 260(2), 232240.

Farzana, K., Akhtar, S., Jabeen, F. (2009) Prevalence 
and antibiotic resistance of bacteria in two ethnic milk based products. Pakistan Journal of Botany, 41, 935-943.

Ferretti, R., Mannazzu, I., Cocolin, L., Comi, G., Clementi, F. (2001) Twelve-hour PCR-based method for detection of Salmonella serovars in food. Applied and Environmental Microbiology, 67, 977-978.

Finegold, S.M., Martin, W.J. (1982) Enterobacteriaceae and non fermentative gram negative bacilli. In: "Bailey and Scott's Diagnostic Microbiology", Finegold, S.M. and Martin, W.J. (Eds), pp. 199-239, $249-265,6^{\text {th }}$ ed. CV Mosby Company, St-Louis. Toronto London.

François, Z.N., Victor, S.D., Florence, F.A. (2012) Characterization and selection of Lactobacilli with probiotic properties from cow's raw milk of Bororo cattle breeders in Dschang (Cameroon). Current Research Journal of Biological Sciences, 4, 143152.

Gill, C., McGinnis, J. (2000) Contamination of beef trimmings with Escherichia coli during a carcass breaking process. Food Research International, 33(2), 125-30.

Gill, C.O., Badoni, M. (2005) Recovery of bacteria from poultry carcasses by rinsing, swabbing or excision of skin. Food Microbiology, 22, 101-107.

Goto, S., Enomoto, S. (1970) Nalidixic acid cetrimide agar. A new selective plating medium for the selective isolation of Pseudomonas aeruginosa. Japanese Journal of Microbiology, 14, 65-72.

Harmsen, D., Karch, H. (2004) 16S rDNA for diagnosing pathogens: a living tree. ASM News, 70, 19-24.

Helmy, Y., El-Adawy, H., Abdelwhab, E. (2017) A comprehensive review of common bacterial, parasitic and viral zoonoses at the human-animal interface in Egypt. Pathogens, 6, 33.

Ikeme, I.A. (1990) Meat Science and Technology. A comprehensive approach. Onitsha, Nigeria: Africana - FEP publishers Ltd.

Karmakar, A., Dua, P., Ghosh, C. (2016) Biochemical and molecular analysis of Staphylococcus aureus clinical isolates from hospitalized patients. Canadian Journal of Infectious Diseases and Medical Microbiology, 2016, 1-7. doi. org/10.1155/2016/9041636

Komba, E.V., Komba, E.V., Mkupasi, E.M., Mbyuzi, A.O., Mshamu, S., Mzula, A., Luwumba, D. (2012) Sanitary practices and occurrence of zoonotic conditions in cattle at slaughter in Morogoro Municipality, Tanzania: implications for public health. Tanzania Journal of Health Research, 14, $1-12$.

Liao, S.F., Nyachoti, C.M. (2017) Using probiotics to improve swine gut health and nutrient utilization. Animal Nutrition, 3, 331-343.

Lin, C.K., Hung, C.L., Hsu, S.C., Tsai, C.C., Tsen, H.Y. (2004) An improved PCR primer pair based on 16S rDNA for the specific detection of Salmonella serovars in food samples. Journal of Food Protection, 67(7), 1335-1343.

Magray Siraj Ud Din, M., Kumar, A., Rawat, K.A., Srivastava, S. (2011) Identification of Escherichia coli through analysis of 16S rRNA and 16S-23S rRNA internal transcribed spacer region sequences. Bioinformation, 6(10), 370-371.

Marques, J.D.L., Funck, G.D., Dannenberg, G.D.S., et al. (2017) Bacteriocin-like substances of Lactobacillus curvatus P99: Characterization and application in biodegradable films for control of Listeria monocytogenes in cheese. Food Microbiology, 63, 159-163.

Mitchell, C., Fredricks, D., Agnew, K., Hitti J. (2015) Hydrogen peroxideproducing lactobacilli are associated with lower levels of vaginal interleukin$1 \mathrm{~b}$, independent of bacterial vaginosis. Sexually Transmitted Diseases, 42(7), 358-363.

Moawad, A.A., Hotze, H., Awad, O., Tomaso, H., Neubauer, H., Hafiz, H.M., El-Adawy, H. (2017) Occurrence of Salmonella enteric and Escherichia coli in raw chicken and beef meat in northern Egypt and dissemination of their antibiotic resistance markers. Gut Pathogens, 9(57), 2-13.

Naghmouchi, K., Baah, J., Hober, D., Jouy, E., Rubrecht, C., Sané, F. (2013) Synergistic effect between colistin and bacteriocins in controlling Gram-negative pathogens and their potential to reduce antibiotic toxicity in mammalian epithelial cells. Antimicrobial Agents and Chemotherapy, 57, 2719-2725. 
Oli, A.N., Eze, D.E., Gugu, T.H., Ezeobi, I., Maduagwu, U.N., Ihekwereme, C.P. (2017) Multiantibiotic resistant extended-spectrum beta-lactamase producing bacteria pose a challenge to the effective treatment of wound and skin infections. Pan African Medical Journal, 27, 66.

Petersen, K.E., James, W.O. (1998) Agents, vehicles and casual inference in bacterial foodborne disease outbreaks. Journal of the American Veterinary Medical Association, 212, 1874-1881.

Pfrunder, S., Grossmann, J., Hunziker, P., Brunisholz, R., Gekenidis, M.T., Drissner, D. (2016) Bacillus cereus group-type strain-specific diagnostic peptides. Journal of Proteome Research, 15, 30983107.

Pinto, B., Chenoll, E., Aznar, R. (2005) Identification and typing of foodborne Staphylococcus aureus by PCR-based techniques. Systematic and Applied Microbiology, 28(4), 340-352.

Reda, F.M., Rashad, M.K., Abou Zeid, Azza A., Elsharawy, Marwa N. (2018) Incidence of virulent factors in staphylococci isolated from clinical and foods specimens in Egypt. Egyptian Journal of Botany, 58(3), 501-514

Reddy, P.N., Srirama, K., Dirisala, V.R. (2017) An update on clinical burden, diagnostic tools, and therapeutic options of Staphylococcus aureus. Infectious Diseases, 10, 1-5.

Ricke, S.C. (2003) Perspectives on the use of organic acids and short chain fatty acids as antimicrobials. Poultry Science, 82, 632-639.

Samot, J., Badet, C. (2013) Antibacterial activity of probiotic candidates for oral health. Anaerobe, 19, 69-72.

Sams, A.R. (2001) Poultry meat. In: "Poultry Meat Processing and Quality", $1^{\text {st }}$ ed. New York: Taylor \& Francis, CRC Press. 395p.

Saud, B., Paudel, G., Khichaju, S., Bajracharya, D., Dhungana, G., Awasthi, M.S., Shrestha, V. (2019) Multidrug-resistant bacteria from raw meat of buffalo and chicken, Nepal. Veterinary Medicine International, 2019, 1-7. doi. org/10.1155/2019/7960268.

Seddik, H.A., Bendali, F., Gancel, F., Fliss, I., Spano,
G., Drider, D. (2017) Lactobacillus plantarum and its probiotic and food potentialities. Probiotics and Antimicrobial Proteins, 9, 111-122.

Shahat, H.S., Mohamed, H.M.A., Abd Al-Azeem, M.W., Nasef, S.A. (2019) Molecular detection of some virulence genes in Pseudomonas aeruginosa isolated from chicken embryos and broilers with regard to disinfectant resistance. International Journal of Veterinary Science, 2(2), 52-70.

Sharma, C., Singh, B.P., Thakur, N., Gulati, N., Gupta, S., Mishra, S.K., Panwar, H. (2017) Antibacterial effects of Lactobacillus isolates of curd and human milk origin against food-borne and human pathogens. 3 Biotech. 7(1), 31.

Sneath, P.H.A., Mair, N.S., Sharpe, Elizabeth M., Holt, J.G. (2009) (Eds.) "Bergy's Manual of Systematic Bacteriology", Pub. Williams and Wilkins, 2605.

SPSS (2006) SPSS base 15.0 User's guide. SPSS inc., Chicago, USA.

Surendran Nair, M., Amalaradjo, M.A., Venkitanarayanan, K. (2017) "Antivirulence Properties of Probiotics in Combating Microbial Pathogenesis". New York, NY: Elsevier Ltd. doi: 10.1016/ bs.aambs.2016.12.001.

Suskovic, J., Kos, B., Matosic, S., Besendorf, V. (2001) The effect of bile salts onsurvivaland morphology of apotential probioticstrain. World Journal of Microbiology \& Biotechnology, 16, 673-678.

Truusalu, K., Mikelsaar, R.H., Naaber, P., Karki, T., Kullisaar, T., Zilmer, M., Mikelsaar, M. (2008) Eradication of Salmonella typhimurium infection in a murine model of typhoid fever with the combination of probiotic Lactobacillus fermentum ME-3 and ofloxacin. BMC Microbiology, 8, 132.

Verdenelli, M.C., Ghelfi, F., Silvi, S., Orpianesi, C., Cecchini, C., Cresci, A. (2009) Probiotic properties of Lactobacillus rhamnosus and Lactobacillusparacasei isolated from human faeces. European Journal of Nutrition, 48, 355-363.

Vidaillac, C., Guillon, J., Arpin, C., Forfar-Bares, I., Ba, B.B., Grellet, J., Moreau, S., Caignard, D.H., Jarry, C., Quentin, C. (2007) Synthesis of omeprazole analogues and evaluation of these as potential inhibitors of the multidrug efflux pump NorA of Staphylococcus aureus. Antimicrobial Agents and 
Chemotherapy, 51, 831-838.

Waters, A.E., Content-Cuomo, T., Buchhagen, J., Liu, C.M., Watson, L., Pearce, K., Foster, J.T., Bowers, J., Driebe, E.M., Engelthaler. D.M., Keim, P.S., Price, L.B. (2011) Multidrug-resistant Staphylococcus aureus in US. Meat and Poultry, 52(10), 1227-1230.
G.E. (1985) A phylogenetic definition of the major eubacterial taxa. Systematic and Applied Microbiology, 6, 143-151.

Zhitnitsky, D., Rose, J., Lewinson, O. (2017) The highly synergistic, broad spectrum, antibacterial activity of organic acids and transition metals. Scientific Reports, 7(1). doi: 10.1038/srep44554.

Woese, C.R., Stackebrandt, E., Macke, T.J., Fox,

\section{عزل و تثخيص بعض السلالات البكتيرية الممرضة من بعض أنواع البراع اللحوم الطازجة

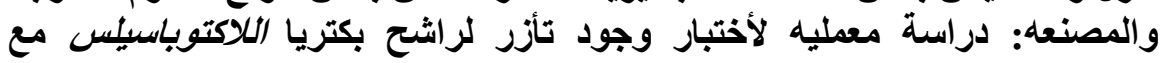 المضاد الحيوي}

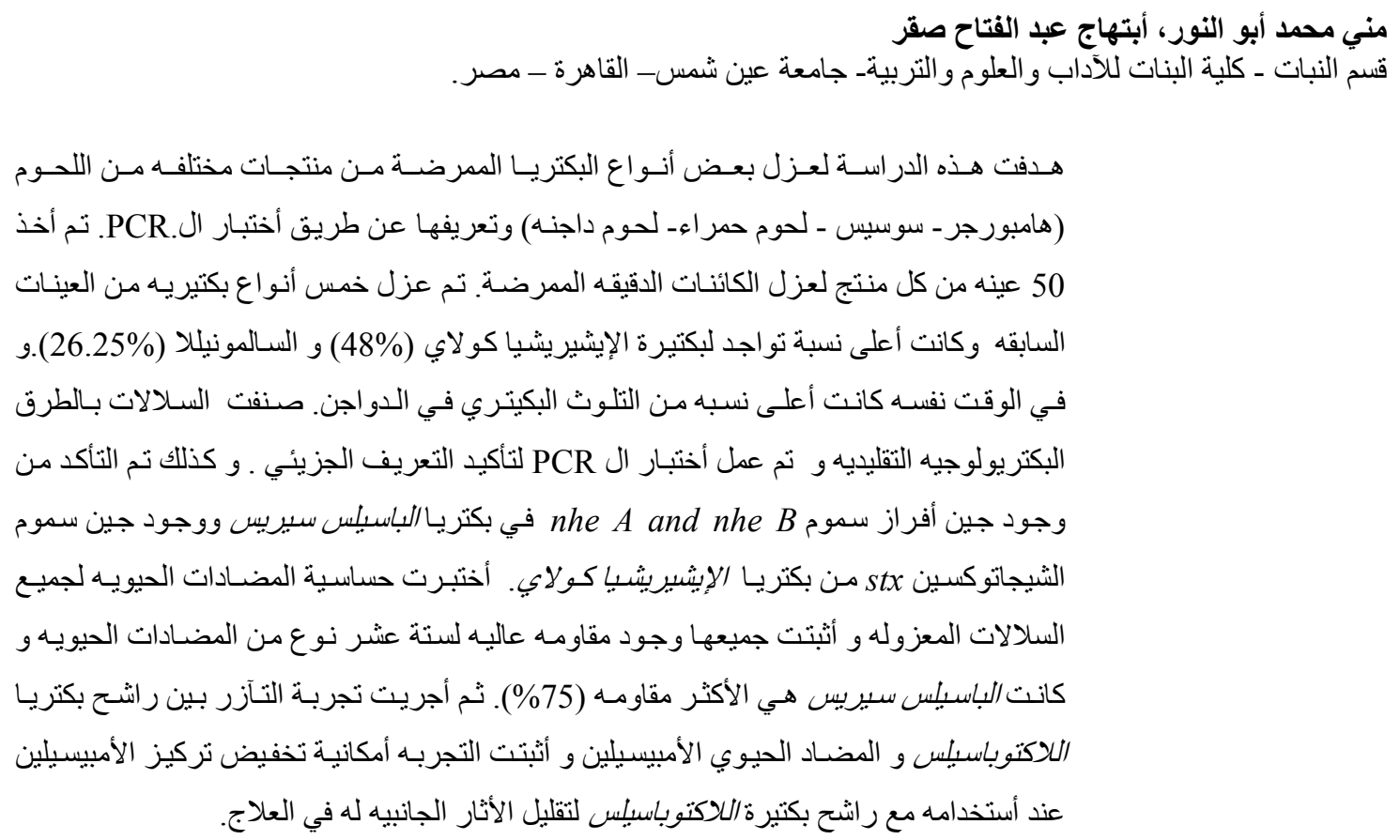

